\title{
PERAN PENDIDIKAN ISLAM GUNA MENCIPTAKAN GENERASI QUR'ANI UNTUK BERPARTISIPASI DALAM KEHIDUPAN BERBANGSA DAN BERNEGARA
}

\section{Suprima}

Universitas Pembangunan Nasional Veteran Jakarta

E-mail: suprima@upnvj.ac.id

\section{Hafidz Noor}

Universitas Pendidikan Indonesia

E-mail: hafidznoorı@@gmail.com

\section{Nurti Budiyanti}

Universitas Pendidikan Indonesia

E-mail: nurtibudiyanti@upi.edu

\section{Muhamad Parhan}

Universitas Pendidikan Indonesia

E-mail: parhan.muhamad@upi.edu

\begin{tabular}{|c|c|c|}
\hline Received & Revised & Accepted \\
\hline 10 Januari 2021 & 10 Februari 2021 & 28 Maret 2021 \\
\hline
\end{tabular}

\section{ROLE OF ISLAMIC EDUCATION TO CREATE QUR'ANI GENERATIONS TO PARTICIPATE IN THE LIFE OF THE NATION AND THE STATE}

\begin{abstract}
As a majority Muslim population in the country of Indonesia, of course, it takes an existence from the Muslim community itself to be able to participate in the life of the nation and state. To participate, it requires a procedure or rules that must be studied first, one of which is through Islamic education. Islamic education has a goal so that the next generation can learn, understand, and apply the Islamic values contained therein. Through Islamic education, it is hoped that later the Muslim population can participate in the life of the nation and state in a polite, polite manner, and not to damage the unity and integrity of the Indonesian nation. Through this research, the author wants to find out how the Muslim population can place a strategic position in the life of the nation and state through the principles in the Qur'an and Hadith.
\end{abstract}

Keyword: Moeslim, Islamic education, and Al Qur'an.

\section{Abstrak}

Sebagai penduduk muslim yang mayoritas di negara Indonesia, tentunya dibutuhkan eksistensi dari masyarakat muslim itu sendiri untuk dapat berpartisipasi dalam kehidupan berbangsa dan bernegara. Untuk berpartisipasi, diperlukan prosedur atau aturan yang harus 
dipelajari terlebih dahulu, salah satunya melalui pendidikan Islam. Pendidikan Islam memiliki tujuan agar generasi penerus dapat mempelajari, memahami, dan menerapkan nilai-nilai Islam yang terkandung di dalamnya. Melalui pendidikan Islam diharapkan nantinya umat Islam dapat berpartisipasi dalam kehidupan berbangsa dan bernegara secara santun, santun, dan tidak merusak persatuan dan kesatuan bangsa Indonesia. Melalui penelitian ini, penulis ingin mengetahui bagaimana umat Islam dapat menempatkan posisi strategis dalam kehidupan berbangsa dan bernegara melalui prinsip-prinsip dalam AlQur'an dan Hadist.

Kata kunci: muslim, pendidikan Islam, dan Al-Qur'an.

\section{Pendahuluan}

Rasulullah SAW pernah bersabda bahwa "barang siapa yang membaca Al Qur'an, mengkaji, menghafal, bahkan mengaplikasikannya dalam kehidupan sehari-hari, pada hari kiamat nanti kedua orangtuanya akan diberikan mahkota yang bersilaukan cahaya sehingga menggemparkan para penduduk langit." Hal tersebut dapat terjadi karena sebagai hadiah kepada orangtua yang telah mengajarkan kepada anaknya betapa penting dan dahsyatya manfaat Al Qur'an ${ }^{1}$.

Oleh karenanya, merupakan sebuah hal yang penting untuk melakukan dan mengaplikasikan pendidikan yang berbasis kepada Al Qur'an kepada anak, saudara, dan masyarakat sekitar. Ketika seluruh sendi kehidupan telah tersentuh dengan Al Qur'an, maka hidup masyarakat tersebut akan dinaungi dan langsung hidup dibawah Al Qur'an. Tak dapat dipungkiri, bahwa Al Qur'an memiliki dampak yang sangat signifikan bagi kehidupan manusia, baik ditinjau dari segi ekonomi, sosial budaya, politik, hingga pendidikan ${ }^{2}$. Mengkaitkan sebuah peristiwa alam yang terjadi dalam kehidupan kita dengan ayat yang ada di Al Qur'an, maka hal tersebut adalah sebagai bentuk kita sebagai manusia untuk mentadabburi Al Qur'an ${ }^{3}$.

Oleh sebab itu, sangat penting untuk mendidik dan membimbing manusia dengan pendidikan islam yang nantinya akan bermuara kepada kalamullah. Manusia merupakan mahkluk Allah SWT yang diberikan akal untuk dapat membedakan hal yang baik ataupun yang buruk. Untuk dapat melatih dan meningkatkan intelektualitas dari akal tersebut, dibutuhkan sebuah latihan ataupun stimulus yang dapat merangsangnya dan salah satunya adalah melalui sebuah pendidikan ${ }^{4}$. Salah satu strateginya adalah melalui pendidikan islam yang berbasis Al Qur'an.

Dari uraian di atas dapat kita ambil sebuah hipotesa bahwa kita diperintahkan utuk mempersiapkan generasi yang kuat, yang punya bekal yang cukup untuk menghadapi tantangan hidup kedepannya. Tujuan dari mempersiapkan generasi yang kuat dan

\footnotetext{
${ }^{1}$ James Piscatori and L. Carl Brown, "Religion and State: The Muslim Approach to Politics," Foreign Affairs 79, no. 5 (2000): 149, https://doi.org/10.2307/20049943.

${ }^{2}$ Nurti Budiyanti, Ahmad Syamsu Rizal, and Elan Sumarna, "IMPLIKASI KONSEP ŪLŪL 'ILMI DALAM ALQUR 'ĀN TERHADAP TEORI PENDIDIKAN ISLAM (Studi Analisis Terhadap Sepuluh Tafsīr Mu'Tabarah)," TARBAWY : Indonesian Journal of Islamic Education, 2016, https://doi.org/10.17509/t.v3i1.3459.

${ }^{3}$ Wedra Aprison, “Mendamaikan Sains Dan Agama: Mempertimbangkan Teori Harun Nasution," Jurnal Pendidikan Islam 4, no. 2 (2015): 241, https://doi.org/10.14421/jpi.2015.42.241-259.

${ }^{4}$ Muhamad Parhan and Bambang Sutedja, "PENERAPAN PENDEKATAN PEMBELAJARAN KONTEKSTUAL DALAM PENDIDIKAN AGAMA ISLAM DI UNIVERSITAS PENDIDIKAN INDONESIA," TARBAWY : Indonesian Journal of Islamic Education 6, no. 2 (November 2019): 114-26, https://doi.org/10.17509/t.v6i2.20165.
} 
berpondasikan nilai-nilai keislaman dapat menjadi sebuah bekal untuk dapat berpartisipasi dalam kehidupan berbangsa dan bernegara. Bekal yang dimaksud disini bukan sekedar harta semata, tetapi lebih meningkatkan intelektualitas pengetahuan secara mendalam serta luas dan yang paling penting selalu berpedoman teguh pada Al Qur'an dalam memecahkan setiap masalah yang ada dihadapannya.

Mencetak berarti menghasilkan sesuatu dengan usaha-usaha tertentu. Mencetak yang dimaksudkan disini adalah menghasilkan generasi dengan usaha-usaha tertentu seperti mendidik, mengarahkan, membimbing, membina manusia untuk memiliki jiwa qur'ani. Membicarakan tentang manusia, makhluk berjiwa, berkepribadian, dan berhati nurani, selalu menarik. Oleh karena itu, baik pembicaraan mengenai aspek luar (fisik) maupun aspek dalam dari diri manusia, seperti jiwa dan hati, tidak pernah selesai ${ }^{5}$.

Dengan demikian, dari paparan yang telah dijelaskan penulis akan mengangkat sebuah permasalahan bagaimana sebuah konsep pendidikan Islam yang berlandaskan kepada Al Qur'an sehingga dapat berpartisipasi dalam aktivitas politik atau untuk hidup dalam kehidupan berbangsa dan bernegara. Sebagai penduduk mayoritas di Indonesia, bagaimana peran setiap muslim dalam berpartisipasi untuk membangun bangsa dan negara melalui pengaplikasian yang telah diajarkan di dalam Al Qur'an.

\section{Metode Penelitian}

Dalam melakukan penelitian ini, penulis memilih menggunakan metode penelitian secara kualitatif deskriptif yang akan mendeskripsikan melalui kata-kata tertulis. Metode penelitian kualitatif juga merupakan metode penelitian yang lebih menekankan pada aspek pemahaman secara mendalam terhadap suatu masalah dari pada melihat permasalahan untuk penelitian generalisasi. Metode penelitian ini lebih suka menggunakan teknik analisis mendalam (indepth analysis), yaitu mengkaji masalah secara kasus perkasus karena metodologi kualitatif yakin bahwa sifat suatu masalah satu akan berbeda dengan sifat dari masalah lainnya.

Sumber data yang digunakan oleh penulis adalah menggunakan data sekunder, data sekunder adalah data yang diperoleh dari dokumendokumen grafis (tabel, catatan, notulen rapat, dll), foto-foto, film, rekaman video, benda-benda, atau penelitian terdahulu yang telah dilakukan oleh peneliti lain, atau bisa dikatakan data yang digunakan oleh penulis adalah mengadopsi dan mengkompilasi dari penelitian yang telah ada tanpa adanya kesamaan yang seragam.

Hasil penelitian kualitatif lebih berorientasi kepada makna daripada generalisasi. Artinya, penelitian kualitatif tidak mengharuskan pada sebuah generalisasi sebuah permasalahan yang diangkat, akan tetapi lebih mengharuskan kepada makna. Dalam konteks penelitian saat ini, penulis akan menjelaskan penelitian secara kualitatif deskriptif dengan menggunakan data sekunder terkait dengan peran Pendidikan Islam untuk dapat berpartisipasi dalam kehidupan berbangsa dan bernegara ${ }^{6}$.

\footnotetext{
${ }^{5}$ Vol No, Tahun Hal, and Menjalankan Sholat, "JCE ( Journal of Childhood Education )" 2, no. 2 (2018): 14775.

${ }^{6}$ MSi. Prof. Dr. Suryana, "Metodologi Penelitian : Metodologi Penelitian Model Prakatis Penelitian Kuantitatif Dan Kualitatif," Universitas Pendidikan Indonesia, 2012, 1-243, https://doi.org/10.1007/s13398014-0173-7.2.
} 


\section{Hasil Penelitian dan Pembahasan Pendidikan Islam}

Pendidikan merupakan usaha yang disengaja untuk membina sikap spiritualitas dan mengembangkan intelektualitas pengetahuan manusia agar dapat menjadikannya sebagai manusia yang paripurna ${ }^{7}$. Artinya, dalam proses pendidikan manusia tidak hanya dibekali dengan intelektualitas semata, akan tetapi dibutuhkan sebuah sikap spiritualitas yang memadai agar memiliki adab dan perilaku. Manusia akan menjadi terhormat dan mulia ketika dapat mengkolaborasikan seluruh aspek yang ada di dalam dirinya seperti aspek intelektualitasnya, spiritualnya, dan emosionalnya ${ }^{8}$. Ketika manusia hanya memikirkan aspek intelektualitasnya, dikhawatirkan manusia tersebut akan menjadi tidak terarah dalam menggunakan akalnya sehingga dapat merugikan bagi oranglain, begitupun sebaliknya. Ada sebuah adagium yang mengatakan bahwa "ilmu tanpa agama akan menjadi pincang dan agama tanpa sebuah ilmu maka akan menjadi buta”.

Mengulas kembali sejarah Islam, bagaimana ketika pengajaran pertama dalam Islam adalah dengan ditandai turunnya malaikat Jibril menemui baginda Nabi Muhammad SAW. yang berada di gua Hira. Dalam pertemuan tersebut, malaikat Jibril meminta kepada Nabi Muhammad SAW. untuk dapat mengikuti apa yang dikatakan atau dibacakannya yaitu surat Al Alaq ayat 1-5. Walaupun pada saat itu Nabi Muhammad SAW belum memahami apa yang dimaksudkan oleh Jibril dan tidak bisa mengucapkan kembali apa yang dikatakan atau dibacakan oleh malaikat Jibril, akan tetapi Jibril terus sabar dalam mengajarkan baginda Nabi Muhammad SAW. Artinya, dalam sebuah pengajaran tersebut adanya proses yang disengaja untuk dapat membina dan membimbing agar memiliki intelektualitas. Selain itu, dalam konteks tadi dapat dikatakan bahwa dalam proses pengajaran dibutuhkan sebuah kesabaran karena tidak bisa serta-merta seseorang yang diajarkan itu dapat mengerti secara langsung bahkan membutuhkan waktu yang cukup lama ${ }^{9}$.

Surat Al Alaq ayat 1-5 merupakan bukti bahwa pengajaran dan pendidikan Islam sebagai pondasi utama setelah adanya iman, islam, dan ihsan. Yaitu terdapat pada ayat Al Qur'an: "Bacalah dengan (menyebut) nama Tuhanmu Yang menciptakan. Dia telah menciptakan manusia dari segumpal darah. Bacalah, dan Tuhanmulah Yang Paling Pemurah. Yang mengajar (manusia) dengan perantaraan kalam. Dia mengajarkan kepada manusia yang tidak diketahuinya."

Dalam pendidikan Islam terdapat tiga materi pokok yang harus diketahui oleh setiap orang yang mempelajarinya, diantaranya adalah mengenal Allah SWT. sebagai pencipta manusia, mengetahui potensi dan fungsi manusia sebagai makhluk ciptaan Allah SWT., dan yang terakhir adalah akhlakul karimah manusia sebagai makhluk ciptaan Allah SWT.

\section{Mengenal Allah SWT.}

a. Mengenal Wujud Allah SWT.

Dalam ajaran Islam, mengenal Allah SWT. merupakan sebuah kewajiban yang harus diimani oleh setiap muslim, iman kepada Allah termasuk ke dalam rukun Iman yang pertama. Setiap ciptaan, peristiwa, atau kejadian yang menimpa dan terjadi di dunia ini

\footnotetext{
${ }^{7}$ Nurti Budiyanti et al., "Konsep Manusia Ideal: Tinjauan Teologis Dan Pendidikan Islam," Al-Tarbawi AlHaditsah: Jurnal Pendidikan Islam 5, no. 2 (2020): 43-67, https://doi.org/10.24235/tarbawi.v5i2.6962.

${ }^{8}$ Mazro'atus Sa'adah, "ARAH PENDIDIKAN ISLAM DALAM AL-QUR'AN," At-Tajdid : Jurnal Ilmu Tarbiyah, 2014.

${ }^{9}$ Saproni, "Metode Pengajaran Nabi Saw, Dan Contoh Aplikasinya Dalam Pengajaran Kelas Mata Kuliah Al Islam Di Universitas Islam Riau," Al Munawwarah 01, no. 01 (2015): 1-15.
} 
merupakan kehendak Allah SWT. Tidak ada yang terjadi dengan cara kebetulan, setiap kejadian, peristiwa, fenomena alam tersebut pasti ada yang menciptakan dan tidak mungkin terjadi dengan sendirinya ${ }^{10}$. Untuk mengimani adanya Allah SWT. adalah dengan cara kita mentadabburi seluruh alam semesta ini, bagaimana alam semesta ini terbentuk, bagaimana langit dapat berdiri dengan kokohnya, tentu itu semua kita lihat dengan pancaindera kita sebagai manusia dibarengi dengan akal pikiran yang telah Allah SWT. anugerahkan kepada manusia. Pengakuan fitrah telah disebutkan oleh Allah SWT. di dalam Al Qur'an surat AlA'raf ayat 172-173, "Dan ingatlah ketika Rabbmu menurunkan keturunan anak-anak Adam dari sulbi mereka dan Allah mengambil kesaksian terhadap jiwa mereka (seraya berfirman): 'Bukankah Aku ini Rabbmu?' Mereka menjawab: '(Betul Engkau Rabb kami) kami mempersaksikannya (Kami lakukan yang demikian itu) agar kalian pada hari kiamat tidak mengatakan: 'Sesungguhnya kami bani Adam adalah orang-orang yang lengah terhadap ini (keesaan-Mu) atau agar kamu tidak mengatakan: 'Sesungguhnya orang-orang tua kami telah mempersekutukan Tuhan sejak dahulu sedangkan kami ini adalah anak-anak keturunan yang datang setelah mereka."

\section{b. Mengenal Rububiyah Allah SWT.}

Dalam mendidik generasi Islam yang berlandaskan Qur'ani, tentunya mengenal Allah secara mendalam akan meningkatkan keimanan dan ketakwaan kita dalam beribadah maupun beraktivitas. Sebagai umat muslim, meyakini keesaan rubibiyah Allah adalah bahwa hanya Allah yang mencipta, memiliki, menguasai, mengontrol seluruh makhluk hidup yang berdiri diatas muka bumi ini. Allah pula yang menghidupkan, mematikan, hingga memberikan rezeki kepada seluruh makhluk hidup yang ada, semuanya tidak terlepas dari pandangan Allah SWT.. Hanya Allah yang berhak disembah dan dengan kekuasaannya menunjukkan bahwa Allah itu Esa, tidak ada yang bisa menandingi kehebatan dan kekuasaan Allah SWT.. Hal tersebut tertulis di dalam surat Al- Fatihah ayat 2, "Segala puji bagi Allah, Rabb (Pemilik, Penguasa) semesta alam", dan surat Al- Ikhlas ayat 1-4, “'Katakanlah!' Dialah Allah yang Maha Esa. Allah adalah Tuhan yang bergantung kepada-Nya segala sesuatu. Dia tidak beranak dan tidak diperanakkan. Dan tidak ada seorangpun yang setara dengan-Nya."

Bahwa Allah sebagai khaliq dan malik, Pencipta segala sesuatu, Pemberi rizki, Yang Menghidupkan, Yang Mematikan, Yang Memberi Petunjuk, Yang Mengurus dan Menetapkan aturan. Keyakinan seperti ini, bisa dikatakan tauhid bila telah bersaksi tidak ada tuhan selain Allah, dan Allah adalah yang berhak disembah tanpa mempersekutukanNya dengan sesuatu. Segala sesuatu selain Allah adalah makhluk. Allah adalah yang memberi manfaat dan madharat kepada makhluk- Nya. Tidak ada orang yang bisa menolak dan menghalangi kehendak- Nya. ${ }^{\text {"I }}$.

\section{c. Mengenal Uluhiyah Allah SWT.}

Cara mengenal Allah yang terakhir adalah dengan uluhiyah, telah dijelaskan bahwa para sahabat Nabi memahami Lã ilāha illa Allāh sebagai tiada sesembahan selain Allah. Hal ini menunjukkan bahwa mereka mengesakan Allah dengan tauhid ulūhiyyah. Ibnu 'Abbas RA juga menjelaskan bahwa makna lafz al- Jalālah "Allah" adalah dzū al-Ulūhiyyah wa al-

\footnotetext{
${ }^{10}$ Solusi Antisipatif, Radikalisme Keagamaan, and Ahmad Mursyidi, “Konsep Makrifat Menurut Al-Ghazali Dan Ibnu 'Arabi: Solusi Antisipatif Radikalisme Keagamaan Berbasis Epistemologi," Jurnal Kawistara 3, no. 1 (2013): 68-78, https://doi.org/10.22146/kawistara.3962.

${ }^{11}$ Daria J Kuss et al., “Metadata, Citation and Similar Papers at Core.Ac.Uk,” 2013, 1-19.
} 
Ma'būdiyyah yang artinya: "Yang memiliki hak disembah dan diibadahi". Dengan kata "ulūhiyyah" ini, Ibnu 'Abbas hakikatnya telah mengkonsep tauhid ulūhiyyah, bahwa hanya Allah semata yang layak dan patut disembah. Tentu hal ini tidak mengherankan, karena telah maklum bahwa Nabi SAW diutus di tengah-tengah bangsa pagan yang menyembah ratusan berhala ${ }^{12}$.

Tujuan dari pengenalan keesaan uluhiyah ini adalah agar generasi muda dapat mencintai Allah SWT. secara utuh dengan tidak adanya sarat akan kepentingan, tunduk kepada-Nya, takut dan berharap hanya kepada-Nya. Bahwa hal ini sangat penting dikarenakan dewasa saat ini, banyak masyarakat yang melupakan untuk beribadah kepada Allah, mereka hanya datang kepada Allah disaat susah dan sempit sedangkan ketika mereka lapang dan bahagia lantas lupa kepada Allah SWT.. Inilah yang harus kita hindari, bahwa dalam kondisi apapun kita harus selalu mengingat Allah agar kita sebagai manusia senantiasa selalu berada di dalam naungan dan lindungan-Nya. Allah telah berfirman dalam Al Qur'an surat Al- Fatihah ayat 5, "Hanya kepada-Mu ya Allah kami menyembah dan hanya kepada-Mu ya Allah kami meminta”.

\section{Kompetensi dan Hakikat Manusia}

Manusia merupakan makhluk hidup ciptaan Allah SWT. yang memiliki perbedaan sangat signifikan dengan makhluk lainnya, manusia dapat lebih mulia daripada malaikat apabila manusia memiliki ketaatan yang tinggi, manusia pun dapat lebih buruk daripada iblis/setan apabila manusia memiliki ketaatan yang sangat rendah, dan manusia dapat lebih hina daripada binatang apabila kelakuannya menyerupai binatang tersebut. Untuk dapat menghindari hal-hal demikian, Allah SWT. telah menganugerahkan akal dan pikiran kepada manusia agar dapat mengendalikan nafsunya sehingga tidak berbuat hal yang demikian (melakukan perbuatan buruk)

Selain itu, akal dan pikiran yang diberikan itu agar manusia dapat mempelajari apa saja yang terjadi di muka bumi ini, manusia dapat menggunakan akal pikirannya untuk mengembangkan teknologi, untuk mendapatkan ilmu pengetahuan, dan sebagainya namun harus ingat bahwa semua yang didapati itu harus kita syukuri dan harus selalu mengingat kepada Allah SWT ${ }^{13}$.

Keistimewaan yang telah Allah anugerahkan kepada manusia antara lain adalah kemampuan berfikir untuk memahami alam semesta terdapat di dalam surat Ar- Rad ayat 3, "Dan Dia yang menghamparkan bumi dan menjadikan gunung-gunung dan sungai-sungai di atasnya. Dan padanya Dia menjadikan semua buah-buahan berpasang-pasangan; Dia menutupkan malam kepada siang. Sungguh, pada yang demikian itu terdapat tanda-tanda (kebesaran Allah) bagi orang-orang yang berpikir." Selain itu, akal untuk memahami tandatanda keagungan Allah terdapat di dalam surat Al -Hajj ayat 46, "Maka tidak pernahkah mereka berjalan di bumi, sehingga hati (akal) mereka dapat memahami, telinga mereka dapat mendengar? Sebenarnya bukan mata itu yang buta, tetapi yang buta ialah hati yang di dalam dada." Semua ayat tersebut adalah menandakan bahwa manusia dapat lebih mulia daripada malaikat, sedangkan ayat yang berisikan bahwa manusia pun dapat menjadi jahat dengan menggunakan akal nya terdapat di dalam surat Yusuf ayat 53, "Dan aku tidak (menyatakan) diriku bebas (dari kesalahan), karena sesungguhnya nafsu itu selalu mendorong kepada

\footnotetext{
${ }^{12}$ Tinjauan Tafsir, Hadits Bahasa, and Lalu Heri Afrizal, "Rubu > Biyah Dan Ulu > Hiyyah Sebagai Konsep Tauhid" 2, no. 01 (n.d.): 41-74.

${ }^{13}$ Prima Aswirna and Reza Fahmi, "Al-Qur'an and Human Mind: The Facts of Science Development," Walisongo: Jurnal Penelitian Sosial Keagamaan 23, no. 2 (2015): 437, https://doi.org/10.21580/ws.23.2.288.
} 
kejahatan, kecuali (nafsu) yang diberi rahmat oleh Tuhanku. Sesungguhnya Tuhanku Maha Pengampun, Maha Penyayang."

\section{Akhlaq}

Akhlak merupakan bagian yang sangat vital dan harus dimiliki oleh setiap muslim. Sebab misi Nabi dalam dakwahnya adalah memperbaiki akhlak umat manusia, sebagai mana sabdanya: "Innama buitstu li utammima makarim al-akhlak", bahwasanya aku diutus untuk menyempurnakan akhlak. Dengan adanya akhlaq di dalam setiap diri manusia, dapat dipastikan bahwa manusia tersebut akan terhindar dari segala perbuatan yang merugikan orang lain dan cenderung selalu memberikan dampak positif terhadap lingkungannya. Dari makna yang terkandung dalam nilai- nilai akhlak ini, maka generasi dewasa saat ini dalam mengembangkan ipteks dan budaya serta aspek- aspek kehidupan lainnya tidak terlepas dari landasan moral dan etika. ${ }^{14}$.

\section{PEMBAHASAN}

\section{Tujuan Pendidikan Islam}

Pendidikan sebagai usaha membina dan mengembangkan pribadi manusia; aspek rohaniah, dan jasmaniah, juga harus berlangsung secara bertahap. Sebab tidak ada satupun makhluk ciptaan Allah yang secara langsung tercipta dengan sempurna tanpa melalui suatu proses. Kematangan dan kesempurnaan yang diharapkan bertitik tolak pada pengoptimalan kemampuannya dan potensinya. Tujuan yang diharapkan tersebut mencakup dimensi vertikal sebagai hamba Tuhan; dan dimensi horisontal sebagai makhluk individual dan sosial. Hal ini dimaknai bahwa tujuan pendidikan dalam pengoptimalan kemampuan atau potensi manusia terdapat keseimbangan dan keserasian hidup dalam berbagai dimensi ${ }^{15}$

Ada tiga komponen dasar manusia yang dibawa sejak lahir. Komponenkomponen tersebut adalah tubuh atau jasad, ruh, dan akal. Satu diantaranya yaitu jasmani, berkembang sesuai dengan sunatullah artinya apabila manusia itu mengkonsumsi nutrisi makanan yang cukup ia akan tumbun dan berkembang layaknya tumbuh-tumbuhan dan makhluk lainnya. Sementara ruh dan akal berkembang untuk mengeksplorasi dirinya melalui proses pendidikan. Ketiganya, merupakan kesatuan yang utuh dan bulat dan tak terpisahkan. Oleh karena itu tujuan pendidikan tidak boleh mengabaikan salah satu unsurunsur dasariah manusia agar masing-masing berkembang dan terjaga dengan baik. Kegagalan pendidikan dalam memproduksi unsur-unsur tersebut menyebabkan hasilnya tidak kualified bagi manusia dalam menjalankan peran khalifah.

Ada beberapa pendapat pro kontra berpandangan berangkat dari pandangan ini kemudian menimbulkan pro dan kontra diantara para ahli. Mereka yang kontra berpandangan berangkat dari paradigma filsafat ilmu, yakni kerangka dasar ilmu harus berawal dari pengalaman empiris bukan dari wahyu yang kebenarannya sudah mutlak dan sulit dibuktikan secara empiris, karena bukan kajian keilmuan. Padahal Islam tidak seperti itu, menurut pendapat H.A.R Gibb sebagaimana dikutib Jalaluddin, Islam bukan ajaran agama semata dan Islam hanya sistem nilai teologi semata, melainkan Islam juga suatu sistem peradaban yang lengkap. Artinya Islam itu adalah ajaran yang bersumber dari wahyu

\footnotetext{
${ }^{14}$ Abdul Rahman, "Pendidikan Agama Islam Dan Pendidikan Islam - Tinjauan Epistemologi Dan Isi - Materi," Eksis 8, no. 1 (2012): 2053-59.

${ }^{15}$ Waston Waston and Miftahudin Rois, "PENDIDIKAN ANAK DALAM PERSPEKTIF PSIKOLOGI ISLAM (STUDI PEMIKIRAN PROF. DR. ZAKIYAH DARADJAT)," Profetika: Jurnal Studi Islam, 2017, https://doi.org/10.23917/profetika.v18i1.6298.
} 
Tuhan.Tujuan pendidikan Islam, tidak sekedar aspek duniawi (konkrit) saja tetapi juga aspek ukhrawi (abstrak) dan fungsional, maka dalam kajian ini penulis membagi menjadi dua bagian, yaitu: tujuan umum dan tujuan khusus pendidikan Islam yang masing-masing saling terkait dan fungsional. Paradigma filsafat ilmu, yakni kerangka dasar ilmu harus berawal dari pengalaman empiris bukan dari wahyu yang kebenarannya sudah mutlak dan sulit dibuktikan secara empiris, karena bukan kajian keilmuan.

Padahal Islam tidak seperti itu, Islam bukan ajaran agama semata dan Islam hanya sistem nilai teologi semata, melainkan Islam juga suatu sistem peradaban yang lengkap. Artinya Islam itu adalah ajaran yang bersumber dari wahyu Tuhan. Tujuan pendidikan Islam, tidak sekedar aspek duniawi (konkrit) saja tetapi juga aspek ukhrawi (abstrak) dan fungsional, maka dalam kajian ini penulis membagi menjadi dua bagian, yaitu: tujuan umum dan tujuan khusus pendidikan Islam yang masing-masing saling terkait dan fungsional ${ }^{16}$.

Pakar-pakar pendidikan Islam, seperti Al-Abrasy mengelompokkan tujuan umum pendidikan Islam menjadi lima bagian, yaitu:

a) Membentuk akhlak yang mulia. Tujuan ini telah disepakati oleh orang-orang Islam bahwa inti dari pendidikan Islam adalah mencapai akhlak yang mulia, sebagaimana misi kerasulan Muhammad SAW;

b) Mempersiapkan peserta didik untuk kehidupan dunia dan akhirat;

c) Mempersiapkan peserta didik dalam dunia usaha (mencari rizki) yang profesional;

d) Menumbuhkan semangat ilmiah kepada peserta didik untuk selalu belajar dan mengkaji ilmu;

e) Mempersiapkan peserta didik yang profesional dalam bidang teknik dan pertukangan.

\section{Implementasi Nilai-Nilai Qur'ani}

Penerapan adalah perbuatan menerapkan. Penerapan merupakan suatu tindakan yang dilakukan secara individu maupun kelompok untuk mencapai tujuan yang telah dirumuskan. Nilai adalah suatu perangkat keyakinan atau perasaan yang diyakini sebagai suatu identitas yang memberikan corak yang khusus kepada pola pemikiran dan perasaan, keterkaitan maupun perilaku. Al-Qur'an merupakan sumber ajaran Islam yang berhubungan dengan totalitas kehidupan manusia yang mengandung pesan sosial dan spirit keagamaan. Realita di tengah masyarakat, tidak dapat dipungkiri bahwa ketika sumber ajaran itu hendak dipahami dan dikomunikasikan dalam kehidupan manusia yang pluralistik, maka diperlukan keterlibatan pemikiran yang merupakan kreativitas manusia, dalam hal ini, manusia menjadikan al-Qur'an sebagai pedoman karena al-Qur'an merupakan kitab suci yang selalu terjaga dari pemalsuan, betapapun ujian datang silih berganti ${ }^{17}$. Adapun nilainilai Qur'ani di antaranya:

\section{1) Nilai Kebenaran}

Nilai kebenaran adalah nilai yang bersumber dari unsur akal manusia (rasio, budi, cipta). Adanya kebenaran itu selalu dihubungkan dengan pengetahuan yang dimiliki manusia (subyek yang mengetahui) mengenai obyek. Jadi, kebenaran itu terdapat pada seberapa jauh subyek mempunyai pengetahuan mengenai obyek. Sedangkan pengetahuan berasal dari berbagai sumber. Sumber- sumber tersebut kemudian berfungsi sebagai ukuran kebenaran. Nilai kebenaran meliputi metafisis dan saintis.

\footnotetext{
${ }^{16}$ Imam Syafi'e, “Tujan Pendidikan Islam” 6, no. November (2015): 1-16.

${ }^{17}$ Japon Riyanta, “Jurnal Aksioma Ad-Diniyah,” Jurnal Aksioma Ad-Diniyah 7, no. 1 (2019): 1-28.
} 


\section{2) Nilai Moral}

Nilai-nilai Qur'ani yaitu sifat yang menjadikan hal itu berguna dan diinginkan bagi manusia sehingga dapat menjadi dasar perbuatan dan membentuk etika lebih baik dengan melibatkan semua potensi yang dimilikinya yaitu seseorang yang dapat berfikir, bersikap, bertindak, mengamalkan serta mendakwahkan bacaan Al-Qur'an dan mencerminkan akhlak seperti yang diajarkan dalam Al-Qur'an dan tiada pedoman yang sempurna selain Al-Qur'an. Jadi, penerapan nilai-nilai Qur'ani yaitu suatu cara yang dilakukan oleh pendidik baik pada saat pembelajaran maupun diluar pembelajaran dalam mengaitkan ilmu pengetahuan, kehidupan, ataupun yang lainnya dengan ayat-ayat yang terkandung dalam Al- Qur'an maupun hadits ${ }^{18}$.

\section{Partisipasi Pendidikan Islam dalam Kehidupan Berbangsa dan Bernegara}

Al-Quran telah memberi isyarat bahwa permasalahan pendidikan sangat penting, jika Al-Quran dikaji lebih mendalam maka kita akan menemukan beberapa prinsip dasar pendidikan, yang selanjutnya bisa kita jadikan inspirasi untuk dikembangkan dalam rangka membangun pendidikan yang bermutu. Ada beberapa indikasi yang terdapat dalam AlQuran yang berkaitan dengan pendidikan antara lain; Menghormati akal manusia, bimbingan ilmiah, fitrah manusia, penggunaan cerita (kisah) untuk tujuan pendidikan dan memelihara keperluan sosial masyarakat ${ }^{19}$.

Dalam kondisi apapun, Allah Swt memerintahkan kepada umat Islam untuk senantiasa berakhlak yang baik, termasuk dalam kehidupan berbangsa dan bernegara.Namun, sebelum menjelaskan tentang etika atau lebih khusus lagi akhlak dalam bernegara alangkah baiknya dijelaskan tentang beberapa hak dan kewajiban seorang warga negara dalam konteks Negara Kesatuan Republik Indonesia. Hak warga negara dapat diartikan sebagai sesuatu yang dapat dimiliki oleh setiap warga negara dari negaranya yang diatur oleh undang-undang sedangkan kewajiban warga negara adalah sesuatu yang harus dilakukan oleh setiap warga negara terhadap negaranya.

Disamping itu, hak-hak sebagai warga negara tercantum dalam UUD 1945 diantaranya adalah hak untuk mendapatkan pekerjaan yang layak (Pasal 27 Ayat 2), hak untuk ikut serta dalam membela negara (Pasal 27 Ayat 3), hak untuk berpendapat (Pasal 28), hak untuk mendapatkan kebebasan beragama (Pasal 29), hak dalam pertahanan dan keamanan (Pasal 30 Ayat 1), hak untuk mendapatkan pengajaran (Pasal 31 Ayat 1), hak untuk mengembangkan dan memajukan kebudayaan (Pasal 32 Ayat 1), hak untuk mendapatkan kesejahteraan ekonomi dan sosial (Pasal 33), dan hak bagi fakir miskin dan orang-orang terlantar untuk mendapatkan perhatian dari negara. Sedangkan kewajiban warga negara terhadap negaranya adalah menjunjung tinggi hukum dan pemerintahan tanpa kecuali (Pasal 27 Ayat 1), kewajiban membela negara (Pasal 27 Ayat 3), dan ikut serta dalam usaha pertahanan dan keamanan negara (Pasal 30 Ayat 1).

Dengan penjelasan tersebut dapat dikatakan bahwa adanya hubungan timbal balik antara negara dan warga negaranya, oleh karena itu sudah sepatutnya sebagai seorang muslim untuk menjalankan segala kewajiban-kewajiban kita sebagai warga negara. Secara garis besar, setidaknya ada tiga etika seorang muslim dalam kehidupan berbangsa dan bernegara, yaitu menegakkan keadilan dan kebenaran, menegakkan nilai-nilai kemanusiaan, dan mewujudkan kemaslahatan umat.

\footnotetext{
${ }^{18}$ Niken Ayu and Dinar Utami, "PENERAPAN NILAI-NILAI QUR' ANI DALAM MEMBANGUN KARAKTER SISWA PROGRAM STUDI PENDIDIKAN AGAMA ISLAM,” 2020.

${ }^{19}$ A L Furqan, S Ag, and M Ag, “Pendidikan Islam Dalam Kajian,” 2010.
} 
Pertama, menegakkan keadilan dan kebenaran. Dalam kehidupan, kebenaran dan keadilan adalah sesuatu yang paling dicari oleh setiap manusia bahkan kehidupan manusia itu sendiri disebut sebagai proses dalam mencari keadilan dan kebenaran. Islam adalah agama yang akan selalu berpihak kepada keadilan dan kebenaran bahkan menegakkan keadilan dan kebenaran adalah kewajiban bagi setiap muslim kapan saja dan dimana saja. Karena saking pentingnya keadilan dalam kehidupan manusia, Allah Swt memerintahkan kepada orang-orang beriman agar selalu menegakkan keadilan dan kebenaran sebagaimana yang tercantum dalam Al-Qur'an surat Al-Maidah ayat 8.

Kedua, menegakkan nilai-nilai kemanusiaan. Secara genealogis, manusia diciptakan oleh Allah Swt dari jenis yang sama, dari nenek moyang yang sama dan dari bahan yang sama. Persamaan inilah yang menjadi dasar pentingnya menegakkan nilai-nilai kemanusiaan. Penegakkan nilai-nilai kemanusiaan dalam Islam menjadi tujuan diturunkannya syariat (maqashidus syari'ah) yang mencakup lima hal, yaitu hak beragama (hifdhzud din), hak hidup (hifdhzun nafs), hak intelektual (hifdhzul 'aql), hak kekayaan (hifdhzul maal), dan hak keturunan (hifdhzun nasl). Secara sosiologis, ajaran Islam akan mengerucut pada lima hal tersebut karena lima hal tersebut merupakan sesuatu yang sangat primer dan utama dalam kehidupan manusia. Dengan demikian, seorang muslim berkewajiban menegakkan pentingnya nilai-nilai kemanusiaan dalam kehidupan berbangsa dan bernegara apabila ini terwujud maka cita-cita menjadi negara yang baldatun thayyibatun warabbun ghafur akan tercapai.

Ketiga, mewujudkan kemaslahatan umat.Inti daripada syariat Islam adalah terwujudnya kemaslahatan umat. Kemaslahatan ini bisa bersifat materil maupun non materil, baik untuk dirinya dan juga untuk orang lain. Kemaslahatan adalah sesuatu yang bersifat universal, berlaku dimana saja dan kapan sehingga harus diperjuangkan oleh setiap manusia.Dalam berbangsa dan bernegara, kebijakan atau keputusan hukum harus mengacu kepada terwujudnya kemaslahatan umat bahkan dalam kaidah fikih dikatakan bahwa kebijakan seorang pemimpin harus dikaitkan dengan kemaslahatan. Dengan demikian, peran serta seorang muslim dalam politik secara umum dan kebijakan secara khusus adalah ikut serta mendorong terwujudnya kemaslahatan umat. ${ }^{20}$

\section{Simpulan}

Pendidikan memiliki peran yang sangat vital untuk dapat mencetak generasi yang cerdas, berakhlakul karimah, dan juga dapat bersaing dengan global. Salah satu yang ditekankan dalam penelitian ini adalah bagaimana pendidikan Islam dapat mencetak generasi yang memiliki kompetensi baik dari segi spiritual, intelektual dan emosial yang tentunya berlandaskan serta berpedoman kepada Al Qur'an dan Hadits. Pendidikan Islam memiliki tujuan yang sangat dalam mencetak generasinya, tidak hanya memikirkan duniawi, tetapi dalam pendidikan islam menekankan pula bagaimana relasi antara manusia dengan Allah SWT. Ketika seorang manusia muslim telah memiliki pondasi kuat yang diterimanya melalui pendidikan Islam secara dini, maka dapat dipastikan manusia tersebut akan bersikap baik ketika terjun ke masyarakat.

Sebagai mayoritas penduduk muslim di Indonesia, tentunya sangat mengkhawatirkan apabila penduduk muslim tersebut tidak dapat menduduki posisi strategis di dalam kehidupan berbangsa dan bernegara. Tujuan dari pendidikan Islam yang berlandaskan Qur'an dan Hadits adalah agar mereka dapat siap untuk menduduki posisi tersebut sehingga memiliki sifat yang amanah dan tidak menghianati kepercayaan masyarakat lainnya. Manusia muslim ketika hidup dalam bermasyarakat dan bernegara,

\footnotetext{
${ }^{20}$ Usman Sutisna, “Etika Berbangsa Dan Bernegara Dalam Islam,” Alashriyyah 5, no. 2 (2019): 12.
} 
selalu menerapkan 3 sifat yang diantaranya adalah dapat dipercaya (amanah), tidak khianat, dan perkataannya dapat dipegang (tidak munafik). Itulah yang menjadi tujuan penelitian ini bagaimana peran pendidikan Islam dalam mencetak generasi muda nya agar memiliki sifat yang demikian sehingga dapat diterima dengan baik oleh masyarakat dan memberikan dampak yang positif.

Ketika sebuah negara dipenuhi oleh lingkungan yang positif dan posisi strategis diisi oleh orang yang tepat, maka dipastikan negara tersebut semakin mendekati kepada kesejahteraan nasional dan diharapkan dapat memberikan keadilan yang seluas-luasnya bagi kehidupan masyarakat. Sama hal nya ketika pada zaman Rasulullah SAW bagaimana kepemimpinan saat itu sangatlah baik, tidak ada orang miskin yang kelaparan bahkan saat pembagian zakat pun pemimpinnya itu sangat pusing kepada siapa dia akan membagikan zakat karena sudah sejahteranya masyarakat tersebut.

Sebagai agama universal, Islam mengatur seluruh aspek kehidupan manusia baik aspek mikro maupun makro termasuk dalam hal ini adalah terkait tentang kehidupan berbangsa dan bernegara.Ajaran Islam menekankan pentingnya etika atau akhlak dalam kehidupan berbangsa dan bernegara agar terwujudnya kehidupan yang damai, tenteram dan sentosa.Etika atau akhlak berbangsa dan bernegara dalam Islam dapat diwujudkan dengan menegakkan keadilan dan kebenaran, menegakkan nilai-nilai kemanusiaan, dan mewujudkan kemaslahatan umat.Dalam konteks Negara Kesatuan Republik Indonesia, terdapat empat pilar dalam kehidupan berbangsa dan bernegara yaitu Pancasila, UUD 1945, NKRI, dan Bhineka Tunggal Ika.Empat pilar tersebut jika ditelusuri dan dipahami secara mendalam maka tidak ada yang bertentangan dengan ajaran-ajaran Islam sehingga perlu didukung dan diimplementasikan oleh seluruh warga negara Indonesia. Jikapun di dalamnya terdapat kekurangan, kelemahan atau kekeliruan maka bisa direvisi sesuai dengan prosedur yang berlaku.

\section{DAFTAR PUSTAKA}

Antisipatif, Solusi, Radikalisme Keagamaan, and Ahmad Mursyidi. "Konsep Makrifat Menurut Al-Ghazali Dan Ibnu 'Arabi: Solusi Antisipatif Radikalisme Keagamaan Berbasis Epistemologi.” Jurnal Kawistara 3, no. 1 (2013): 68-78. https://doi.org/10.22146/kawistara.3962.

Aprison, Wedra. "Mendamaikan Sains Dan Agama: Mempertimbangkan Teori Harun Nasution.” Jurnal Pendidikan Islam 4, no. 2 (2015): 241. https://doi.org/10.14421/jpi.2015.42.241-259.

Aswirna, Prima, and Reza Fahmi. "Al-Qur'an and Human Mind: The Facts of Science Development." Walisongo: Jurnal Penelitian Sosial Keagamaan 23, no. 2 (2015): 437. https://doi.org/10.2158o/ws.23.2.288.

Ayu, Niken, and Dinar Utami. "PENERAPAN NILAI-NILAI QUR ' ANI DALAM MEMBANGUN KARAKTER SISWA PROGRAM STUDI PENDIDIKAN AGAMA ISLAM," 2020.

Budiyanti, Nurti, Asep Abdul Aziz, Andewi Suhartini, Nurwadjah Ahmad, and Ari Prayoga. "Konsep Manusia Ideal: Tinjauan Teologis Dan Pendidikan Islam." Al-Tarbawi AlHaditsah: Jurnal Pendidikan Islam 5, no. 2 (2020): 43-67. https://doi.org/10.24235/tarbawi.v5i2.6962.

Budiyanti, Nurti, Ahmad Syamsu Rizal, and Elan Sumarna. "IMPLIKASI KONSEP ŪLŪL 'ILMI DALAM AL-QUR'ĀN TERHADAP TEORI PENDIDIKAN ISLAM (Studi Analisis Terhadap Sepuluh Tafsīr Mu'Tabarah).” TARBAWY : Indonesian Journal of Islamic Education, 2016. https://doi.org/10.17509/t.v3i1.3459. 
Furqan, A L, S Ag, and M Ag. "Pendidikan Islam Dalam Kajian,” 2010.

Kuss, Daria J, Mark D Griffiths, Jens F Binder, and Burton Street. "Metadata, Citation and Similar Papers at Core.Ac.Uk," 2013, 1-19.

No, Vol, Tahun Hal, and Menjalankan Sholat. "JCE ( Journal of Childhood Education )" 2, no. 2 (2018): 147-75.

Parhan, Muhamad, and Bambang Sutedja. "PENERAPAN PENDEKATAN PEMBELAJARAN KONTEKSTUAL DALAM PENDIDIKAN AGAMA ISLAM DI UNIVERSITAS PENDIDIKAN INDONESIA." TARBAWY : Indonesian Journal of Islamic Education 6, no. 2 (November 2019): 114-26. https://doi.org/10.17509/t.v6i2.20165.

Piscatori, James, and L. Carl Brown. "Religion and State: The Muslim Approach to Politics." Foreign Affairs 79, no. 5 (2000): 149. https://doi.org/10.2307/20049943.

Prof. Dr. Suryana, MSi. "Metodologi Penelitian : Metodologi Penelitian Model Prakatis Penelitian Kuantitatif Dan Kualitatif." Universitas Pendidikan Indonesia, 2012, 1-243. https://doi.org/10.1007/s13398-014-0173-7.2.

Rahman, Abdul. "Pendidikan Agama Islam Dan Pendidikan Islam - Tinjauan Epistemologi Dan Isi - Materi." Eksis 8, no. 1 (2012): 2053-59.

Riyanta, Japon. "Jurnal Aksioma Ad-Diniyah." Jurnal Aksioma Ad-Diniyah 7, no. 1 (2019): 128.

Sa'adah, Mazro’atus. “ARAH PENDIDIKAN ISLAM DALAM AL-QUR'AN.” At-Tajdid : Jurnal Ilmu Tarbiyah, 2014.

Saproni. "Metode Pengajaran Nabi Saw, Dan Contoh Aplikasinya Dalam Pengajaran Kelas Mata Kuliah Al Islam Di Universitas Islam Riau." Al Munawwarah o1, no. o1 (2015): 1-15.

Sutisna, Usman. "Etika Berbangsa Dan Bernegara Dalam Islam.” Alashriyyah 5, no. 2 (2019): 12.

Syafi'e, Imam. “Tujan Pendidikan Islam” 6, no. November (2015): 1-16.

Tafsir, Tinjauan, Hadits Bahasa, and Lalu Heri Afrizal. "Rubu > Biyah Dan Ulu > Hiyyah Sebagai Konsep Tauhid" 2, no. or (n.d.): 41-74.

Waston, Waston, and Miftahudin Rois. "PENDIDIKAN ANAK DALAM PERSPEKTIF PSIKOLOGI ISLAM (STUDI PEMIKIRAN PROF. DR. ZAKIYAH DARADJAT)." Profetika: Jurnal Studi Islam, 2017. https://doi.org/10.23917/profetika.v18i1.6298. 